\title{
Anticancer effects of methotrexate in combination with $\alpha$-tocopherol and $\alpha$-tocopherol succinate on triple-negative breast cancer
}

\author{
CHYOU-WEI WEI ${ }^{1,2^{*}}$, YUNG-LUEN YU ${ }^{3-6^{*}}$, YU-HSUN CHEN ${ }^{1}$, YU-TING HUNG ${ }^{1,3}$ and GIOU-TENG YIANG ${ }^{7,8}$ \\ ${ }^{1}$ Department of Nutrition, Master Program of Biomedical Nutrition, and ${ }^{2}$ Department of Nursing, Hungkuang University, \\ Taichung 433; ${ }^{3}$ Graduate Institute of Biomedical Sciences, and ${ }^{4}$ Drug Development Center, China Medical University; \\ ${ }^{5}$ Center for Molecular Medicine, China Medical University Hospital, Taichung 404; ${ }^{6}$ Department of Biotechnology, \\ Asia University, Taichung 413; ${ }^{7}$ Department of Emergency Medicine, Taipei Tzu Chi Hospital, \\ Buddhist Tzu Chi Medical Foundation, New Taipei City 231; ${ }^{8}$ Department of Emergency Medicine, \\ School of Medicine, Tzu Chi University, Hualien 970, Taiwan, R.O.C.
}

Received March 9, 2018; Accepted January 7, 2019

DOI: 10.3892/or.2019.6958

\begin{abstract}
Triple-negative breast cancers (TNBCs) lack the estrogen receptor, progesterone receptor (PR) and human epidermal growth factor receptor 2 (HER2). Therefore, hormone or targeted therapies are not effective in the treatment of TNBC and thus the development of novel therapeutic strategies is crucial. Methotrexate (MTX), a folate antagonist, has been used in the treatment of various types of cancer; however, the anticancer effects of MTX treatment on breast cancer have thus far been ineffective. Vitamin $\mathrm{E}$ variants and derivatives have been applied for cancer therapy. Previous studies have indicated that vitamin E variants and derivatives exert distinct anticancer effects on different types of cancer. However, whether MTX plus vitamin E variants or its derivatives can inhibit TNBC remains unclear. The aim of the present study was to examine the anticancer effects and mechanisms of action of MTX in combination with vitamin $\mathrm{E}$ variants ( $\alpha$-tocopherol) and derivatives ( $\alpha$-tocopherol succinate) on TNBC. In the present study, MTT assay and western blot analysis were used to determine the cell survival rates and protein levels. The results demonstrated that combination treatment with MTX and $\alpha$-tocopherol suppressed TNBC cell proliferation. In addition, various concentrations of MTX exerted distinct cytotoxic effects on $\alpha$-tocopherol succinate-treated cells. Furthermore, high-dose MTX enhanced
\end{abstract}

Correspondence to: Dr Giou-Teng Yiang, Department of Emergency Medicine, Taipei Tzu Chi Hospital, Buddhist Tzu Chi Medical Foundation, 289 Jianguo Road, Xindian, New Taipei City 231, Taiwan, R.O.C.

E-mail: gioutengyiang@gmail.com; jtyiang@tzuchi.com.tw

${ }^{*}$ Contributed equally

Key words: methotrexate, $\alpha$-tocopherol, $\alpha$-tocopherol succinate $\alpha$-tocopherol succinate-induced anticancer activity; however, low-dose MTX inhibited $\alpha$-tocopherol succinate-induced anticancer activity. The present study also demonstrated that caspase- 3 activation and poly(adenosine diphosphate-ribose) polymerase cleavage were observed in the $\alpha$-tocopherol succinate/MTX-treated cells. In conclusion, the findings of the present study demonstrated that high-dose MTX enhanced anticancer activity in $\alpha$-TOS-treated TNBC, while low-dose MTX reduced anticancer activity in $\alpha$-TOS-treated TNBC.

\section{Introduction}

Breast cancer is a common type of non-skin malignant tumor affecting women (1). A previous study revealed that $\sim 1.67$ million breast cancer cases are diagnosed each year worldwide (2). Breast cancers with or without estrogen receptor (ER), progesterone receptor (PR) and human epidermal growth factor receptor 2 (HER2) can be divided into hormone-dependent and -independent breast cancers $(3,4)$. It is considered that $\sim 15-20 \%$ of breast cancer cells lack ER, PR and EGFR2, and thus are classed as triple-negative breast cancers (TNBCs) $(5,6)$. As TNBCs lack hormone receptors, hormone or targeted therapies are not effective in the treatment of TNBCs in clinical practice $(7,8)$. Thus, the development of novel treatment strategies for TNBCs is of utmost importance.

Methotrexate (MTX) is known as a folate antagonist used widely in the treatment of rheumatoid arthritis and cancer $(9,10)$. Low-dose MTX has been shown to exert anti-inflammatory effects when used in the treatment of rheumatoid arthritis; however, high-dose MTX has been shown to have anti-proliferative cytotoxic activities with a number of side-effects, such as renal damage $(9,11,12)$. Previous studies have suggested that MTX can induce cell cytotoxicity which is related to increases in reactive oxygen species (ROS) production $(13,14)$. Furthermore, a number of studies have demonstrated that MTX can inhibit cell proliferation in various types of cancers including lung cancer, lymphoma, leukemia and hepatoma (15-19). However, to date, to the best 
of our knowledge, no previous study has demonstrated that MTX alone can exert sufficient anticancer effects on breast cancer. In order to enhance the anticancer effects of MTX on breast cancer, combination treatment with MTX with other agents has been considered (4,20,21).

Vitamin E is known as a fat-soluble vitamin with anti-oxidative function (22). Vitamin $\mathrm{E}$ has 8 variants, including 4 tocopherols $(\alpha-, \beta-, \gamma$ - and $\delta$-tocopherols) and 4 tocotrienols $(\alpha-, \beta-, \gamma-$ and $\delta$-tocotrienols); it has also been demonstrated to lower cancer risk (23-25). $\alpha$-tocopherol is a major variant found in vitamin $\mathrm{E}$ and has anti-oxidative functions $(26,27)$. The majority of studies have suggested that $\gamma$ - and $\delta$-tocopherol and $\gamma$ - and $\delta$-tocotrienol can inhibit breast cancer growth, while $\alpha$-tocopherol does not exert obvious anticancer activity in breast cancer $(25,28)$. Studies have demonstrated that $\gamma$ - and $\delta$-tocopherol only inhibit ER-positive $\left(\mathrm{ER}^{+}\right)$breast cancer, while $\gamma$ - and $\delta$-tocotrienol can inhibit both $\mathrm{ER}^{+}$breast cancer and TNBC $(23,28)$. In addition, a previous study also revealed that high-dose $(100 \mu \mathrm{M}) \alpha$-tocopherol inhibited cell proliferation in $\mathrm{ER}^{+}$breast cancer, including MCF-7 and T47D cells in a dose-dependent manner (29). Previous studies have also demonstrated that only $\alpha$-tocopherol succinate ( $\alpha$-TOS) has potent antioxidant activities, while $\gamma$ - and $\delta$-tocotrienol do not (22-27). Clinical MTX treatment can induce oxidative stress resulting in side-effects $(9,11,12)$; therefore, perhaps MTX-induced oxidative stress can be decreased by the use of $\alpha$-TOS. Therefore, whether $\alpha$-tocopherol has potent anticancer activities in breast cancer warrants further investigation.

$\alpha$-TOS is an analogue of $\alpha$-tocopherol with anticancer activity (30-32). Previous studies have revealed that $\alpha$-TOS has anticancer activities in various hormone-dependent breast cancers, such as MCF-7, MDA-MB-435, 4T1 and MDA-MB-453 cells (33-36). Another previous study demonstrated that $\alpha$-TOS induced the apoptosis of TNBC cells, such as MDA-MB-231 and SKBR-3 cells (37). However, that study only demonstrated that apoptotic characteristics and Fas signals were induced in $\alpha$-TOS-treated cells. The other mechanisms associated with $\alpha$-TOS treatment in TNBC warrant further investigation.

Based on the above-mentioned studies, MTX, vitamin E and its analogue have been previously administered in the treatment of breast cancers. The present study aimed to determine whether combination treatment with MTX and vitamin $\mathrm{E}$ or its analogue may have more potential for use in the treatment of TNBCs. The anticancer effects on TNBC were determined following treatment with MTX, $\alpha$-tocopherol, $\alpha$-TOS, MTX/ $\alpha$-tocopherol and MTX/ $\alpha$-TOS.

\section{Materials and methods}

Materials, reagents and antibodies. Fetal bovine serum, Dulbecco's modified Eagle's medium (DMEM), non-essential amino acids, L-glutamine and penicillin/streptomycin were obtained from Gibco/Thermo Fisher Scientific, Inc. (Waltham, MA, USA). The MTT assay kit was obtained from Bio Basic Canada Inc. (Markham, OT, Canada). Luminol, lucigenin, $\alpha$-tocopherol, $\alpha$-TOS and Hoechst 33342 were purchased from Sigma-Aldrich/Merck KGaA (Darmstadt, Germany). Anti-tubulin (1:1,000; cat. no. BS1699) primary rabbit polyclonal antibody was acquired from Bioworld Technology, Inc.
(Louis Park, MN, USA). Anti-cleaved poly(adenosine diphosphate-ribose) polymerase (PARP; 1:2000; cat. no. 9544) and anti-caspase-3 (1:1000; cat. no.9665) primary rabbit polyclonal antibodies and horseradish peroxidase (HRP)-conjugated goat anti-rabbit IgG secondary antibody (1:2,000; cat. no. 7074) were purchased from Cell Signaling Technology, Inc. (Danvers, MA, USA).

Cells and cell culture. The TNBC cell lines, MDA-MB-231 and MDA-MB-468, were purchased from the Bioresource Collection and Research Center (Shin Chu, Taiwan). The cells were cultured with DMEM supplemented with $10 \%$ fetal bovine serum, $0.1 \mathrm{mM}$ non-essential amino acids, $2 \mathrm{mM}$ L-glutamine and $100 \mathrm{IU} / \mathrm{ml}$ penicillin/streptomycin and maintained at $37^{\circ} \mathrm{C}$ with a humidified atmosphere containing $5 \% \mathrm{CO}_{2}$.

Cell survival rate assay. The cell survival rate was determined using an MTT assay. The cells were cultured in 96-well dish ( $3 \times 10^{3}$ cells/well). Every $24 \mathrm{~h}$, the control and experimental groups (MTX, vitamin E, MTX/vitamin E treatments) were treated with the MTT kit. The cells were incubated with MTT solution for $3 \mathrm{~h}$ at $37^{\circ} \mathrm{C}$ and the formazan product was produced. The formazan product was dissolved and the absorbance was determined at $570 \mathrm{~nm}$ (A570) using a Multiskan ${ }^{\mathrm{TM}}$ FC Microplate Photometer (Molecular Devices LLC, Sunnyvale, CA, USA). The survival rate (\%) was calculated as [(A570 experimental group)/(A570 control group)] x 100\%.

Measurements of intracellular $\mathrm{H}_{2} \mathrm{O}_{2}$. The production of cellular $\mathrm{H}_{2} \mathrm{O}_{2}$ was determined using the lucigenin-amplified chemiluminescence method $(38,39)$. The control and experimental samples $(200 \mu \mathrm{l})$ were treated with $0.2 \mathrm{mmol} / \mathrm{ml}$ of luminol solution $(100 \mu \mathrm{l})$ to determine the $\mathrm{H}_{2} \mathrm{O}_{2}$ levels. All samples were analyzed and observed for $5 \mathrm{~min}$ using a chemiluminescence analyzing system (CLA-FSI; Tohoko Electronic Industrial Co., Ltd., Sendai, Japan).

SDS electrophoresis and western blot analysis. The control and experimental cells were treated with lysis buffer (radio-immunoprecipitation assay buffer; cat. no. 20-188; EMD Millipore, Billerica, MA, USA). Following centrifugation $\left(16,000 \mathrm{x} \mathrm{g} ; 4^{\circ} \mathrm{C}\right)$ for $30 \mathrm{~min}$, proteins were obtained from the supernatant layer. The protein concentration was determined using a protein assay kit (cat. no. 23200; Thermo Fischer Scientific, Inc.). A total of $40 \mu \mathrm{g}$ protein was loaded and separated on $13.3 \%$ SDS-PAGE under 80 volts. Separated proteins were transferred onto PVDF membranes (EMD Millipore). The membranes were firstly blocked with $5 \%$ non-fat milk at room temperature for $2 \mathrm{~h}$. After washing with phosphate-buffered saline (PBS) for $15 \mathrm{~min}$ (3 times), the membranes were treated with primary antibodies for $4 \mathrm{~h}$ at room temperature, and the membranes were then washed with PBS for 15 min (3 times). The membranes were subsequently incubated with anti-rabbit HRP-conjugated secondary antibodies (1:2,000; cat. no. 7074; Cell Signaling Technology, Inc.) at room temperature for $1 \mathrm{~h}$. Finally, immunolabeled proteins were added and incubated with Western Lightning ${ }^{\circledR}$ Chemiluminescence Plus reagent (PerkinElmer, Inc., Waltham, MA, USA). The protein band was observed 
and analyzed with a Luminescence Image Analysis system (LAS-4000; FUJIFILM Electronic Materials Taiwan Co., Ltd., Taiwan) and ImageJ 1.51j8 by Wayne Rasband (National Institutes of Health, Bethesda, MD, USA).

Statistical analysis. All data were obtained and calculated from 3 or 4 independent experiments. Values are expressed as the means $\pm \mathrm{SD}$ and analyzed using one-way ANOVA (SPSS for Windows, version 10; SPSS, Inc., Chicago, IL, USA) followed by Tukey's test for the comparisons of group means. All statistical analyses were performed using SAS for Windows, version 9.4. The level of significance was set at a P-value $<0.05$.

\section{Results}

Combined treatment with MTX and $\alpha$-tocopherol suppresses the proliferation of TNBC cells. MTX and $\alpha$-tocopherol were used to treat the TNBC MDA-MB-231 cells. The survival rates were $\sim 90 \%$ following $72 \mathrm{~h}$ of treatment with $0.1 \mu \mathrm{M}$ MTX, $10 \mu \mathrm{M}$ MTX and $5 \mu \mathrm{M} \alpha$-tocopherol in the MDA-MB231 cells (Fig. 1). These results indicated that MTX alone and $\alpha$-tocopherol alone did not effectively suppress the proliferation of the MDA-MB-231 cells. Combined treatment with MTX and $\alpha$-tocopherol was then applied in the MDA-MB-231 cells. The survival rate was $\sim 75 \%$ following treatment of the MDA-MB231 cells with $0.1 \mu \mathrm{M}$ MTX plus $5 \mu \mathrm{M} \alpha$-tocopherol (Fig. 2A). In addition, the survival rate was below $70 \%$ following treatment of the MDA-MB231 cells with $10 \mu \mathrm{M}$ MTX plus $5 \mu \mathrm{M} \alpha$-tocopherol (Fig. 2B). As shown in Fig. 2, when compared with the group treated with MTX alone, the group treated with MTX plus $\alpha$-tocopherol (MTX/ $\alpha$-tocopherol) exhibited significantly lower survival rates at 48 and $72 \mathrm{~h}$. These data suggested that MTX/ $\alpha$-tocopherol treatment suppressed the proliferation of the MDA-MB-231 cells. However, the survival rate was above $60 \%$ in the MTX/ $\alpha$-tocopherol-treated group following $72 \mathrm{~h}$ of treatment. Thus, it was considered that MTX/ $\alpha$-tocopherol may only attenuate cell proliferation and thus MTX/ $\alpha$-tocopherol treatment may be not be an effective strategy for clinical treatment.

$\alpha$-tocopherol decreases the $\mathrm{H}_{2} \mathrm{O}_{2}$ levels in MTX-treated cells. Previous studies have demonstrated that MTX can induce an increase in ROS in cells, particularly $\mathrm{H}_{2} \mathrm{O}_{2}$ levels, causing cell cytotoxicity $(14,19)$. In the present study, we wished to determine whether MTX also induces an increase in $\mathrm{H}_{2} \mathrm{O}_{2}$ levels in MDA-MB-231 cells. Compared to the control group, treatment with $10 \mu \mathrm{M}$ MTX significantly increased the $\mathrm{H}_{2} \mathrm{O}_{2}$ levels in the MDA-MB-231 cells, while treatment with $0.1 \mu \mathrm{M}$ MTX did not markedly increase the $\mathrm{H}_{2} \mathrm{O}_{2}$ levels (Fig. 3A). These results indicated that MTX increases the $\mathrm{H}_{2} \mathrm{O}_{2}$ levels in a dose-dependent manner. $\alpha$-tocopherol is known to have anti-oxidative activities $(26,27)$. In the present study, whether $\alpha$-tocopherol can inhibit the MTX-induced increase in $\mathrm{H}_{2} \mathrm{O}_{2}$ levels was investigated. The results revealed that $\alpha$-tocopherol decreased the $\mathrm{H}_{2} \mathrm{O}_{2}$ levels in the MTX-treated cells (Fig. 3B). Notably, as shown in Figs. 2 and 3, the $\mathrm{H}_{2} \mathrm{O}_{2}$ levels were not associated with cell proliferation in the MTX-treated and MTX/ $\alpha$-tocopherol-treated MDA-MB-231 cells.

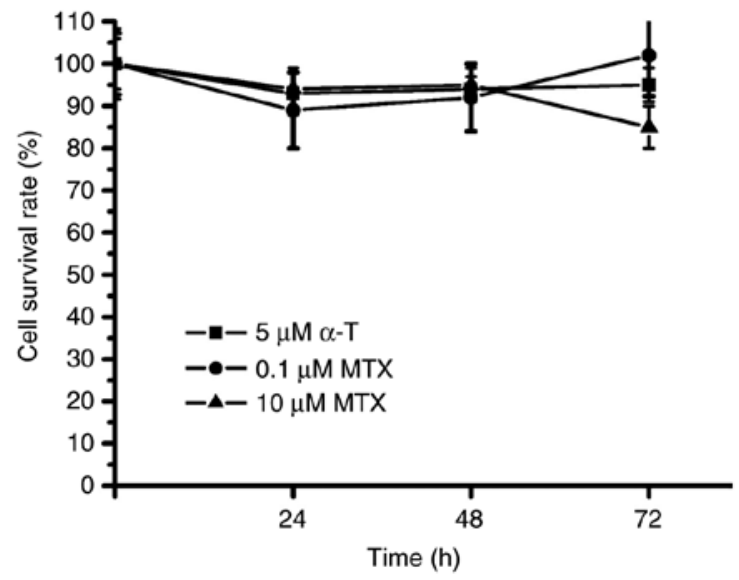

Figure 1. MTX alone and $\alpha$-tocopherol alone do not induce cytotoxicity. MDA-MB-231 cells were incubated with 0.1 and $10 \mu \mathrm{M}$ MTX and $5 \mu \mathrm{M}$ $\alpha$-tocopherol for $72 \mathrm{~h}$. Every $24 \mathrm{~h}$, the samples were treated with an MTT kit. Survival rates were calculated as (A570 experimental group/A570 control group) $x 100 \%$. Data were analyzed from 4 independent experiments and are presented as the means \pm standard deviation. MTX, methotrexate; $\alpha-T$, $\alpha$-tocopherol.

$\alpha-T O S$ induces cell cytotoxicity in TNBC in a time- and concentration-dependent manner. A previous study indicated that $\alpha$-TOS induces the apoptosis of and Fas activation in breast cancer cells (37). In the present study, the concentration of $\alpha$-TOS and the incubation time were further investigated in the $\alpha$-TOS-treated MDA-MB-231 cells. As shown in Fig. 4, the cell survival rate was $\sim 90 \%$ following treatment of the MDA-MB-231 cells with 5 and $20 \mu \mathrm{M} \alpha-\operatorname{TOS}$ for $72 \mathrm{~h}$; however, the cell survival rate at $72 \mathrm{~h}$ was $\sim 50 \%$ following treatment with $40 \mu \mathrm{M} \alpha$-TOS and below $50 \%$ following treatment of the MDA-MB-231 cells with 60 and $80 \mu \mathrm{M} \alpha$-TOS. These results indicated that $\alpha$-TOS induced cytotoxicity in a concentration-dependent manner. Furthermore, following treatment with 40,60 and $80 \mu \mathrm{M} \alpha$-TOS, the survival rates of the MDA-MB-231 cells gradually decreased during the 72 -h treatment period. Thus, $\alpha$-TOS induced cytotoxicity in a time-dependent manner.

High- and low-dose MTX induces distinct cytotoxicity in $\alpha$-TOS-treated TNBC cells. Our data demonstrated that MTX/a-tocopherol treatment suppressed TNBC cell proliferation, although MTX/ $\alpha$-tocopherol induced-anticancer activity was ineffective (Fig. 2). The present study further investigated the anticancer effects on MDA-MB-231 cells following treatment with MTX plus $\alpha$-TOS, or $\alpha$-tocopherol derivatives. The 72-h cell survival rate was $\sim 50 \%$ following treatment of the MDA-MB-231 cell with $40 \mu \mathrm{M} \alpha$-TOS alone (Fig. 5). Notably, the 72-h MDA-MB-231 cell survival rate was $\sim 35 \%$ in the group treated with $40 \mu \mathrm{M} \alpha$-TOS plus $10 \mu \mathrm{M}$ MTX; however, it was $\sim 60 \%$ in the $40 \mu \mathrm{M} \alpha$-TOS plus $0.1 \mu \mathrm{M}$ MTX group (Fig. 5). During the 72-h treatment period, the survival rate curve of the group treated with $40 \mu \mathrm{M} \alpha$-TOS plus $10 \mu \mathrm{M}$ MTX was below that of the group treated with $40 \mu \mathrm{M} \alpha$-TOS only. However, the survival rate curve of the group treated with $40 \mu \mathrm{M} \alpha$-TOS plus $0.1 \mu \mathrm{M}$ MTX was above that of the group treated with $40 \mu \mathrm{M} \alpha$-TOS alone. Therefore, these results indicated that high-dose MTX enhanced anticancer activity 

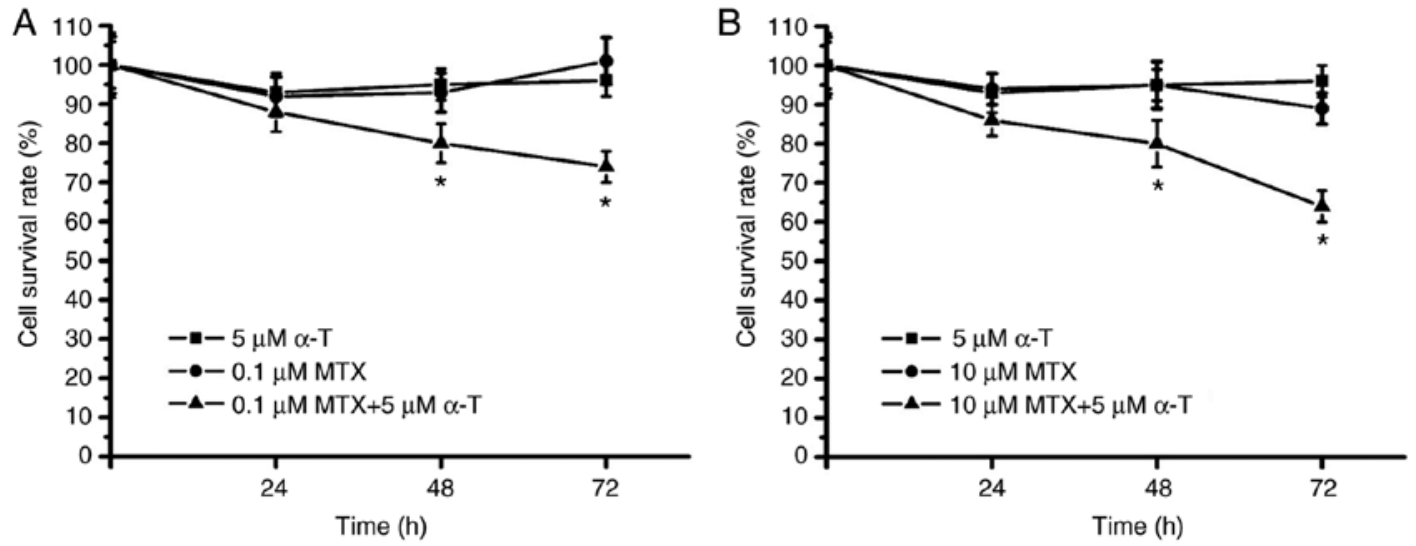

Figure 2. Combined treatment with MTX and $\alpha$-tocopherol exerts a synergistic effect. (A) MDA-MB-231 cells were incubated with $0.1 \mu \mathrm{M}$ MTX, $5 \mu \mathrm{M}$ $\alpha$-tocopherol and $0.1 \mu \mathrm{M}$ MTX plus $5 \mu \mathrm{M} \alpha$-tocopherol, respectively, for $72 \mathrm{~h}$. (B) MDA-MB-231 cells were incubated with $10 \mu \mathrm{M}$ MTX, $5 \mu \mathrm{M} \alpha$-tocopherol and $10 \mu \mathrm{M}$ MTX plus $5 \mu \mathrm{M} \alpha$-tocopherol, respectively, for $72 \mathrm{~h}$. Every $24 \mathrm{~h}$, the samples were treated with an MTT kit. Survival rates were calculated as (A570 experimental group/A570 control group) x 100\%. Data were analyzed from 4 independent experiments and are presented as the means \pm standard deviation. ${ }^{*} \mathrm{P}<0.05$ vs. the group treated with MTX only. MTX, methotrexate; $\alpha-\mathrm{T}, \alpha$-tocopherol.
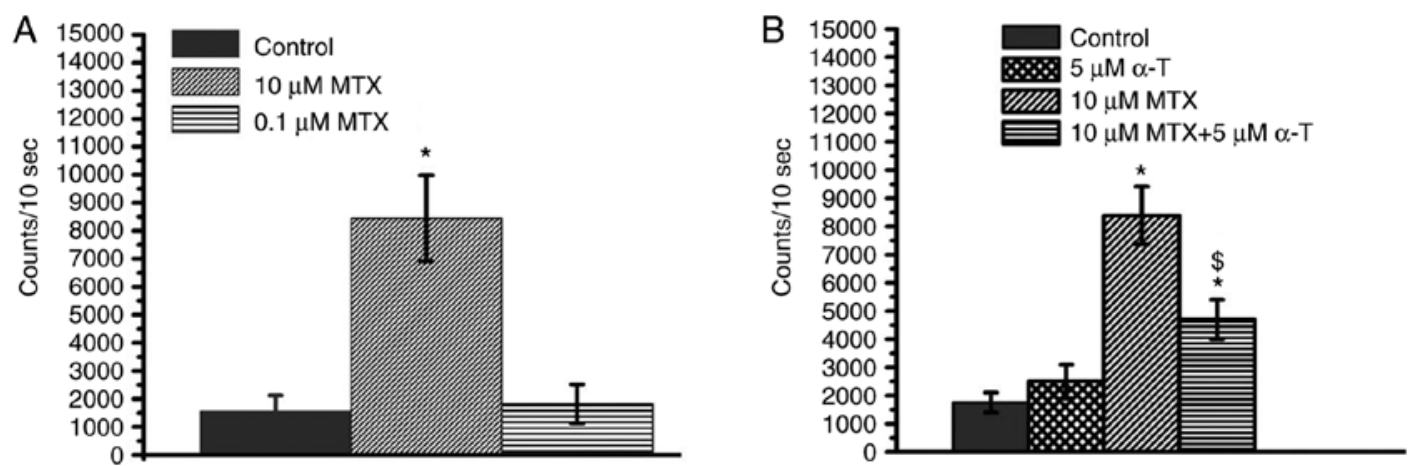

Figure 3. $\alpha$-tocopherol decreases MTX-induced $\mathrm{H}_{2} \mathrm{O}_{2}$ levels. (A) Cells were incubated with 0.1 or $10 \mu \mathrm{M}$ MTX, respectively. (B) Cells were incubated with $10 \mu \mathrm{M}$ MTX or $10 \mu \mathrm{M}$ MTX plus $5 \mu \mathrm{M} \alpha$-tocopherol, respectively. Following a 4-h incubation, samples were treated with luminol solution. Data were analyzed from 4 independent experiments and are presented as the means \pm standard deviation. ${ }^{*} \mathrm{P}<0.05$ vs. the control group; ${ }^{\mathrm{S}} \mathrm{P}<0.05$ vs. the group treated with $10 \mu \mathrm{M}$ MTX only. MTX, methotrexate; $\alpha$-T, $\alpha$-tocopherol.

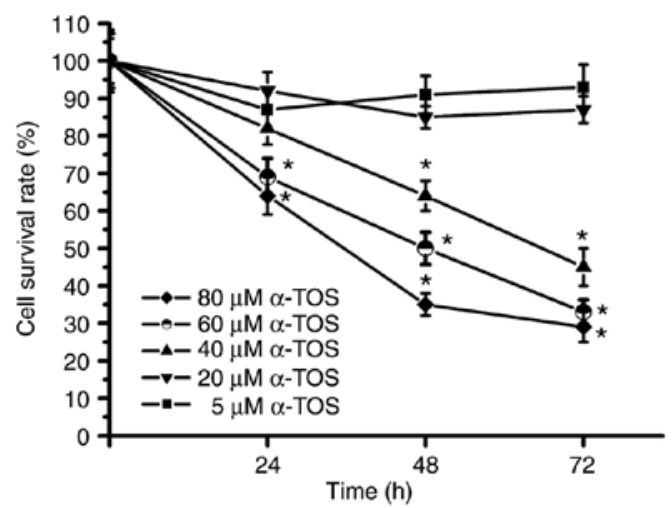

Figure 4. $\alpha$-TOS exerts a dose-dependent cytotoxicity effect. Cells were incubated with 5, 20, 40, 60 and $80 \mu \mathrm{M} \alpha$-TOS, respectively, for $72 \mathrm{~h}$. Every $24 \mathrm{~h}$, the samples were treated with an MTT kit. Survival rates were calculated as (A570 experimental group/A570 control group) x 100\%. Data were analyzed from 4 independent experiments and are presented as the means \pm standard deviation. ${ }^{*} \mathrm{P}<0.05$ vs. the $5 \mu \mathrm{M} \alpha$-TOS group. $\alpha$-TOS, $\alpha$-tocopherol succinate.

in $\alpha$-TOS-treated MDA-MB-231 cells, while low-dose MTX reduced anticancer activity in $\alpha$-TOS-treated MDA-MB-231 cells.

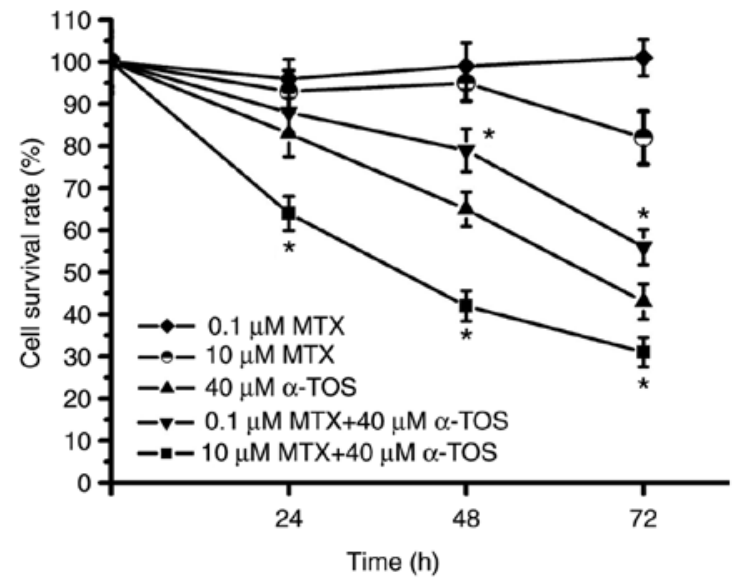

Figure 5. High- and low-dose MTX induce distinct cytotoxicity in $\alpha$-TOS-treated cells. Cells were incubated with $0.1 \mu \mathrm{M}$ MTX, $10 \mu \mathrm{M}$ MTX, $40 \mu \mathrm{M} \alpha$-TOS, $0.1 \mu \mathrm{M}$ MTX plus $40 \mu \mathrm{M} \alpha$-TOS and $10 \mu \mathrm{M}$ MTX plus $40 \mu \mathrm{M}$ $\alpha$-TOS, respectively, for $72 \mathrm{~h}$. Every $24 \mathrm{~h}$, the samples were treated with an MTT kit. Survival rates were calculated as (A570 experimental group/A570 control group) $\mathrm{x} 100 \%$. Data were analyzed from 4 independent experiments and are presented as the means \pm standard deviation. P-values were evaluated among the $40 \mu \mathrm{M} \alpha$-TOS only group, $0.1 \mu \mathrm{M}$ MTX plus $40 \mu \mathrm{M} \alpha$-TOS group and $10 \mu \mathrm{M}$ MTX plus $40 \mu \mathrm{M} \alpha$-TOS group. ${ }^{*} \mathrm{P}<0.05$ vs. the $40 \mu \mathrm{M} \alpha$-TOS only group. MTX, methotrexate; $\alpha$-TOS, $\alpha$-tocopherol succinate. 
A

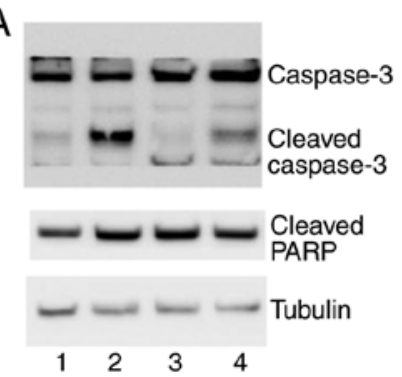

$\mathrm{B}$

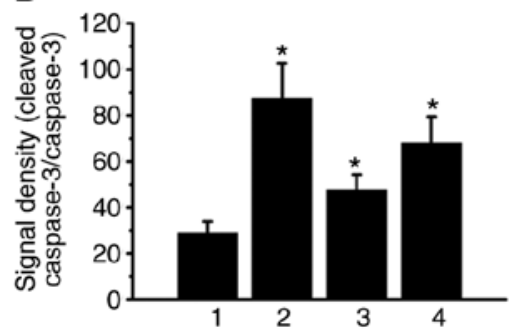

C

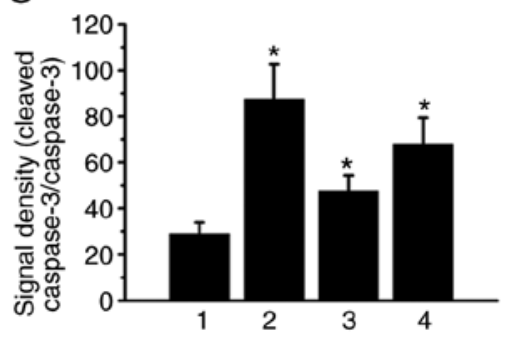

Figure 6. MTX and $\alpha$-TOS induce casepase-3 activation and PARP cleavage. (A) Western blot analysis, (B) cleaved caspase-3/caspase-3 relative intensity and (C) cleaved PARP/tubulin were observed and determined at $72 \mathrm{~h}$ in the control group (lane 1), $40 \mu \mathrm{M} \alpha$-TOS group (lane 2), $0.1 \mu \mathrm{M}$ MTX plus $40 \mu \mathrm{M}$ $\alpha$-TOS group (lane 3) and $10 \mu \mathrm{M}$ MTX plus $40 \mu \mathrm{M} \alpha$-TOS group (lane 4). Data were determined from 3 independent experiments and are presented as the means \pm standard deviation. ${ }^{*} \mathrm{P}<0.05$ vs. the control group. MTX, methotrexate; PARP, poly(adenosine diphosphate-ribose) polymerase; $\alpha$-TOS, $\alpha$-tocopherol succinate.

$\alpha-T O S$ - and MTX/ $\alpha-T O S$-induced cytotoxicity is associated with caspase-3 activation and PARP cleavage. Previous studies have demonstrated that both $\alpha$-TOS and MTX can induce cell cytotoxicity via caspase-3 activation $(19,40,41)$. In the present study, as shown in Fig. 5, treatment with $40 \mu \mathrm{M}$ $\alpha$-TOS, $40 \mu \mathrm{M} \alpha$-TOS/0.1 $\mu \mathrm{M}$ MTX and $40 \mu \mathrm{M} \alpha$-TOS $/ 10 \mu \mathrm{M}$ MTX induced cell cytotoxicity. Thus, caspase-3 activation and PARP, downstream of caspase-3, were investigated in the present study. As determined by western blot analysis, the ratio of cleaved caspase-3/pro-caspase-3 was increased in the $\alpha$-TOS- and $\alpha$-TOS/MTX-treated cells (Fig. 6). In addition, PARP cleavage was also observed in the $\alpha$-TOS- and $\alpha$-TOS/MTX-treated cells (Fig. 6). Therefore, these results indicate that $\alpha$-TOS and $\alpha$-TOS/MTX may induce cell cytotoxicity via caspase-3 activation in MDA-MB-231 cells.

\section{Discussion}

Previous studies have indicated that vitamin E has anti-oxidative functions in cancer chemotherapy, reducing chemical agent-induced side-effects $(42,43)$. Furthermore, vitamin E can prolong the survival of patients with gastric cancer (44) and can attenuate prostate cancer metastasis (45). $\alpha$-tocopherol is the most common form found abundantly in vitamin $\mathrm{E}$ and displays anti-oxidative activity $(42,46)$. $\alpha$-tocopherol is also used to decrease chemical agent-induced side-effects in cancer therapy (47). The low dose of $\operatorname{MTX}(0.1 \mu \mathrm{M})$ used in the present study, is the concentration that is used in clinical practice for the treatment of rheumatoid arthritis. The high dose of MTX $(10 \mu \mathrm{M})$ used in the present study is the dose used in clinical practice for cancer therapy. Currently, a dose of $\geq 10 \mu \mathrm{M}$ MTX is used in clinical practice for cancer therapy. On the other hand, vitamin $\mathrm{E}$ is an antioxidant nutrient, and the dose range of vitamin E used in clinical practice varies widely. Generally, the dose of 5 to $80 \mu \mathrm{M}$ vitamin $\mathrm{E}$ is used for combination treatment in clinical practice for various diseases. Therefore, the dose range of 5 to $80 \mu \mathrm{M}$ vitamin $\mathrm{E}$ was used in the present study. A previous study revealed that $\alpha$-tocopherol enhances the anti-proliferative effects of gefitinib in cells (48). However, $\alpha$-tocopherol may attenuate the anticancer activity of some chemical agents, such as tamoxifen and crizotinib $(49,50)$. The present study demonstrated that treatment with $\alpha$-tocopherol plus MTX decreased the proliferation of MDA-MB-231 cells (Fig. 2). Therefore, it was suggested that $\alpha$-tocopherol may have different anticancer effects when used in combination with different chemical agents. However, the mechanisms through which $\alpha$-tocopherol promotes MTX- and gefitinib-induced cell proliferation and inhibits tamoxifen- and crizotinib-induced anticancer activities remain unclear.

A recent study demonstrated that treatment with vitamin $\mathrm{C} / \mathrm{MTX}$ increased $\mathrm{H}_{2} \mathrm{O}_{2}$ levels, resulting in cell cytotoxicity (4). A number of studies have also revealed that high $\mathrm{H}_{2} \mathrm{O}_{2}$ levels are associated with cell cytotoxicity (51-53). However, the present study demonstrated that $\alpha$-tocopherol attenuated the MTX-induced $\mathrm{H}_{2} \mathrm{O}_{2}$ levels (Fig. 3B), while treatment with $\alpha$-tocopherol plus MTX exerted anti-proliferative effects on MDA-MB-231 cells (Fig. 2). Therefore, it was suggested that the anti-proliferative effects of treatment with $\alpha$-tocopherol/MTX may not be related to the $\mathrm{H}_{2} \mathrm{O}_{2}$ levels. The mechanisms underlying the anti-proliferative activity of $\alpha$-tocopherol/MTX require further investigation in the future.

Previous studies have demonstrated that cyclopentenone prostaglandins $/ \alpha-$ TOS treatment and MTX/ $\alpha$-TOS treatment have synergistic anticancer effects on oral squamous carcinoma cells (54) and osteosarcoma cells (55). Similar to these studies, the data from the present study also demonstrated that high-dose MTX/ $\alpha$-TOS had a synergistic anticancer effect on MDA-MB-231 cells. The survival rate was below $50 \%$ following treatment with high-dose MTX/ $\alpha$-TOS for $48 \mathrm{~h}$ (Fig. 5). Compared with the survival rate of the high-dose MTX/ $\alpha$-TOS treatment group, the survival rate was still above $60 \%$ following treatment with high-dose MTX/ $\alpha$-tocopherol for $72 \mathrm{~h}$ (Fig. 2B). Therefore, it was suggested that high-dose MTX/ $\alpha$-TOS may be a potential treatment for TNBC, while high-dose MTX/ $\alpha$-tocopherol treatment may not be an effective strategy for TNBC treatment.

The present study, as well as previous studies have demonstrated that $\alpha$-tocopherol/MTX and $\alpha$-tocopherol/gefitinib treatment exert synergistic anti-proliferative effects (48). However, previous studies have also revealed that $\alpha$-tocopherol/ tamoxifen and $\alpha$-tocopherol/crizotinib treatment exert antagonistic anti-proliferative effects $(49,50)$. These studies indicate that $\alpha$-tocopherol in combination with different chemical agents has distinct anti-proliferative effects. However, in the present study, high-dose MTX enhanced $\alpha$-TOS-induced cell cytotoxicity, while low-dose MTX antagonized $\alpha$-TOS-induced cell cytotoxicity in MDA-MB-231cells (Fig. 5). This result was similar to that of a previous study (34). This previous 
study demonstrated that high-dose sodium selenite promoted $\alpha$-TOS-induced cell cytotoxicity, while low-dose sodium selenite attenuated $\alpha$-TOS-induced cell cytotoxicity in MCF-7 cells. Based on these studies, it was suggested that both synergistic and antagonistic effects can arise in the same drug components in a dose-dependent manner. Although the detailed signaling mechanisms require further investigation, the results of the present study suggested that caspase signaling (Fig. 6) had a similar mechanism when comparing the low- and high-dose effects of MTX with $\alpha$-TOS treatment. However, oxidative stress (such as $\mathrm{H}_{2} \mathrm{O}_{2}$ levels; Fig. 3) may have different signaling pathways when comparing the low- and high-dose effect of MTX with $\alpha$-TOS treatment. In addition, as shown in Fig. 5, high-dose MTX slightly reduced the cell survival rate, while low-dose MTX slightly increased the cell survival rate. These results may be related to the synergistic or antagonistic anticancer effects caused by $\alpha$-TOS/MTX treatment. Both MDA-MB-231 and MDA-MB-468 were examined in the present study. Similar results were obtained with the MDA-MB-468 cells (data not shown).

In conclusion, the present study demonstrated that combined treatment with MTX and $\alpha$-tocopherol or $\alpha$-TOS attenuated the cell survival rate of TNBC cells. However, MTX/ $\alpha$-TOS exerted a more potent anti-proliferative effect than MTX/ $\alpha$-tocopherol. In addition, high-dose MTX enhanced the $\alpha$-TOS-induced cytotoxic effects, while low-dose MTX antagonized the $\alpha$-TOS-induced cytotoxic effects.

\section{Acknowledgements}

The authors would like to thank the Ministry of Science and Technology, the Ministry of Health and Welfare, the Taipei Tzu Chi Hospital and Drug Development Center, China Medical University (Taiwan, ROC) for making the present study a possibility.

\section{Funding}

The present study was supported by grants from the Ministry of Science and Technology, Taiwan (grant nos. MOST1062320-B-039-051-MY3 and MOST107-2320-B-039-004), the Ministry of Health and Welfare, Taiwan (grant no. MOHW107TDU-B-212-112-015), the Taipei Tzu Chi Hospital, Taiwan (grant nos. TCRD-TPE-106-35, TCRD-TPE-106-36, TCRDTPE-105-20 and TCRD-TPE-105-02) and the study was also financially supported by the 'Drug Development Center, China Medical University' from The Featured Areas Research Center Program within the framework of the Higher Education Sprout Project by the Ministry of Education (MOE) in Taiwan, ROC.

\section{Availability of data and materials}

All data generated or analyzed during the present study are included in this published article or are available from the corresponding author on reasonable request.

\section{Authors' contributions}

CWW and YLY performed the experiments, analyzed the data and wrote the manuscript. YHC and YTH performed the experiments and analyzed the data. GTY designed the experiments and analyzed the data. All authors approved the final version of the manuscript. All authors have read and approved the final manuscript.

\section{Ethics approval and consent to participate}

Not applicable.

\section{Patient consent for publication}

Not applicable.

\section{Competing interests}

The authors declare that they have no competing interests

\section{References}

1. Fan J, Wu Y, Yuan M, Page D, Liu J, Ong IM, Peissig P and Burnside E: Structure-leveraged methods in breast cancer risk prediction. J Mac Learn Res 17: 85, 2017.

2. Ferlay J, Soerjomataram I, Dikshit R, Eser S, Mathers C, Rebelo M, Parkin DM, Forman D and Bray F: Cancer incidence and mortality worldwide: Sources, methods and major patterns in GLOBOCAN 2012. Int J Cancer 136: E359-E386, 2015.

3. Robinson SP and Jordan VC: Antiestrogenic action of toremifene on hormone-dependent, -independent, and heterogeneous breast tumor growth in the athymic mouse. Cancer Res 49: 1758-1762, 1989.

4. Wu CW, Liu HC, Yu YL, Hung YT, Wei CW and Yiang GT: Combined treatment with vitamin $\mathrm{C}$ and methotrexate inhibits triple-negative breast cancer cell growth by increasing $\mathrm{H}_{2} \mathrm{O}_{2}$ accumulation and activating caspase- 3 and p38 pathways. Oncol Rep 37: 2177-2184, 2017.

5. Yu YL, Chou RH, Liang JH, Chang WJ, Su KJ, Tseng YJ, Huang WC, Wang SC and Hung MC: Targeting the EGFR/PCNA signaling suppresses tumor growth of triple-negative breast cancer cells with cell-penetrating PCNA peptides. PLoS One 8: e61362, 2013.

6. Metzger-Filho O, Tutt A, de Azambuja E, Saini KS, Viale G, Loi S, Bradbury I, Bliss JM, Azim HA Jr, Ellis P, et al: Dissecting the heterogeneity of triple-negative breast cancer. J Clin Oncol 30: 1879-1887, 2012.

7. Perou CM, Sørlie T, Eisen MB, van de Rijn M, Jeffrey SS, Rees CA, Pollack JR, Ross DT, Johnsen H, Akslen LA, et al: Molecular portraits of human breast tumours. Nature 406: 747-752, 2000.

8. Williams CB, Soloff AC, Ethier SP and Yeh ES: Perspectives on epidermal growth factor receptor regulation in triple-negative breast cancer: Ligand-mediated mechanisms of receptor regulation and potential for clinical targeting. Adv Cancer Res 127: 253-281, 2015.

9. Malaviya AN: Low-dose methotrexate (LD-MTX) in rheumatology practice-a most widely misunderstood drug. Curr Rheumatol Rev 12: 168-176, 2016.

10. Robien K, Boynton A and Ulrich CM: Pharmacogenetics of folate-related drug targets in cancer treatment. Pharmacogenomics 6: 673-689, 2005.

11. Mori S, Hidaka M, Kawakita T, Hidaka T, Tsuda H, Yoshitama T, Migita K and Ueki Y: Factors associated with myelosuppression related to low-dose methotrexate therapy for inflammatory rheumatic diseases. PLoS One 11: e0154744, 2016.

12. Maejima H, Watarai A, Nakano T, Katayama C, Nishiyama $H$ and Katsuoka K: Adverse effects of methotrexate in three psoriatic arthritis patients. Rheumatol Int 34: 571-574, 2014.

13. Kolli VK, Abraham P, Isaac B and Selvakumar D: Neutrophil infiltration and oxidative stress may play a critical role in methotrexate-induced renal damage. Chemotherapy 55: 83-90, 2009.

14. Cağlar Y, Özgür H, Matur I, Yenilmez ED, Tuli A, GÖnlüşen G and Polat S: Ultrastructural evaluation of the effect of $\mathrm{N}$-acetylcysteine on methotrexate nephrotoxicity in rats. Histol Histopathol 28: 865-874, 2013. 
15. Yang W, Zou Y, Meng F, Zhang J, Cheng R, Deng C and Zhong Z: Efficient and targeted suppression of human lung tumor xenografts in mice with methotrexate sodium encapsulated in all-function-in-one chimeric polymersomes. Adv Mater 28: 8234-8239, 2016.

16. Larsen EC, Devidas M, Chen S, Salzer WL, Raetz EA, Loh ML, Mattano LA Jr, Cole C, Eicher A, Haugan M, et al: Dexamethasone and high-dose methotrexate improve outcome for children and young adults with high-risk B-acute lymphoblastic leukemia: A report from children's oncology group study AALL0232. J Clin Oncol 34: 2380-2388, 2016.

17. Kansara R, Shenkier TN, Connors JM, Sehn LH, Savage KJ, Gerrie AS and Villa D: Rituximab with high-dose methotrexate in primary central nervous system lymphoma. Am J Hematol 90: $1149-1154,2015$

18. Cipolleschi MG, Marzi I, Rovida E, Olivotto $M$ and Dello Sbarba P: Low-dose methotrexate enhances cycling of highly anaplastic cancer cells. Cell Cycle 16: 280-285, 2017.

19. Yiang GT, Chou PL, Hung YT, Chen JN, Chang WJ, Yu YL and Wei CW: Vitamin $\mathrm{C}$ enhances anticancer activity in methotrexate-treated Hep3B hepatocellular carcinoma cells. Oncol Rep 32: 1057-1063, 2014

20. Barros S, Mencia N, Rodriguez L, Oleaga C, Santos C, Noé V and Ciudad CJ: The redox state of cytochrome $\mathrm{c}$ modulates resistance to methotrexate in human MCF7 breast cancer cells. PLoS One 8: e63276, 2013.

21. Tanabe M: Combination chemotherapy of mitomycin $\mathrm{C}$ and methotrexate was effective on metastatic breast cancer resistant to Eribulin, Vinorelbine, and bevacizumab after anthracycline, Taxane, and Capecitabine. Case Rep Oncol 9: 422-426, 2016.

22. Velthuis-te Wierik EJ, van den Berg H, Weststrate JA, van het Hof $\mathrm{KH}$ and de Graaf C: Consumption of reduced-fat products: Effects on parameters of anti-oxidative capacity. Eur J Clin Nutr 50: 214-219, 1996.

23. Smolarek AK, So JY, Burgess B, Kong AN, Reuhl K, Lin Y, Shih WJ, Li G, Lee MJ, Chen YK, et al: Dietary administration of $\delta$ - and $\gamma$-tocopherol inhibits tumorigenesis in the animal model of estrogen receptor-positive, but not HER-2 breast cancer. Cancer Prev Res 5: 1310-1320, 2012.

24. Constantinou C, Papas A and Constantinou AI: Vitamin E and cancer: An insight into the anticancer activities of vitamin $\mathrm{E}$ isomers and analogs. Int J Cancer 123: 739-752, 2008.

25. Smolarek AK and Suh N: Chemopreventive activity of vitamin $E$ in breast cancer: A focus on $\gamma$ - and $\delta$-tocopherol. Nutrients 3 ; 962-986, 2011.

26. Zapata GL, Guajardo MH and Terrasa AM: The in vitro protective effect of alpha-tocopherol on oxidative injury in the dog retina. Vet J 177: 266-272, 2008.

27. Ekstrand-Hammarstrom B, Osterlund C, Lilliehöök B and Bucht A: Vitamin E down-modulates mitogen-activated protein kinases, nuclear factor-kappaB and inflammatory responses in lung epithelial cells. Clin Exp Immunol 147: 359-369, 2007

28. Comitato R, Nesaretnam K, Leoni G, Ambra R, Canali R, Bolli A, Marino M and Virgili F: A novel mechanism of natural vitamin $E$ tocotrienol activity: Involvement of ERbeta signal transduction. Am J Physiol Endocrinol Metab 297: E427-E437, 2009.

29. Chamras H, Barsky SH, Ardashian A, Navasartian D, Heber D and Glaspy JA: Novel interactions of vitamin $\mathrm{E}$ and estrogen in breast cancer. Nutr Cancer 52: 43-48, 2005

30. Gao Y, Qi X, Zheng Y, Ji H, Wu L, Zheng N and Tang J: Nanoemulsion enhances $\alpha$-tocopherol succinate bioavailability in rats. Int J Pharm 515: 506-514, 2016.

31. Kulikov AV, Vdovin AS, Zhivotovsky B and Gogvadze V: Targeting mitochondria by $\alpha$-tocopheryl succinate overcomes hypoxia-mediated tumor cell resistance to treatment. Cell Mol Life Sci 71: 2325-2333, 2014.

32. Angulo-Molina A, Reyes-Leyva J,López-Malo A and Hernández J: The role of alpha tocopheryl succinate $(\alpha-$ TOS $)$ as a potential anticancer agent. Nutr Cancer 66: 167-176, 2014.

33. Yu W, Liao QY, Hantash FM, Sanders BG and Kline K: Activation of extracellular signal-regulated kinase and c-Jun- $\mathrm{NH}_{2}$-terminal kinase but not $\mathrm{p} 38$ mitogen-activated protein kinases is required for RRR- $\alpha$-tocopheryl succinate-induced apoptosis of human breast cancer cells. Cancer Res 61: 6569-6576, 2001.

34. Badr DM, Hafez HF, Agha AM and Shouman SA: The combination of $\alpha$-tocopheryl succinate and sodium selenite on breast cancer: A merit or a demerit? Oxid Med Cell Longev 2016: 4741694,2016
35. Wang XF, Xie Y, Wang HG, Zhang Y, Duan XC and Lu ZJ: $\alpha$-Tocopheryl succinate induces apoptosis in erbB2-expressing breast cancer cell via NF- $\kappa \mathrm{B}$ pathway. Acta Pharmacol Sin 31: $1604-1610,2010$

36. Wang D, Chuang HC, Weng SC, Huang PH, Hsieh HY, Kulp SK and Chen CS: alpha-Tocopheryl succinate as a scaffold to develop potent inhibitors of breast cancer cell adhesion. J Med Chem 52: 5642-5648, 2009

37. Turley JM, Fu T, Ruscetti FW, Mikovits JA, Bertolette DC III and Birchenall-Roberts MC: Vitamin E succinate induces Fas-mediated apoptosis in estrogen receptor-negative human breast cancer cells. Cancer Res 57: 881-890, 1997.

38. Lin BR, Yu CJ, Chen WC, Lee HS, Chang HM, Lee YC, Chien CT and Chen CF: Green tea extract supplement reduces D-galactosamine-induced acute liver injury by inhibition of apoptotic and proinflammatory signaling. J Biomed Sci 16: 35, 2009.

39. Yiang GT, Yu YL, Lin KT, Chen JN, Chang WJ and Wei CW: Acetaminophen induces $\mathrm{JNK} / \mathrm{p} 38$ signaling and activates the caspase-9-3-dependent cell death pathway in human mesenchymal stem cells. Int J Mol Med 36: 485-492, 2015

40. Abe N, Shimizu T, Miyoshi N, Murata Y and Nakamura Y: $\alpha$-Tocopherol sensitizes human leukemia HL-60 cells to apoptosis induced by benzyl isothiocyanate. Biosci Biotechnol Biochem 76: 381-383, 2012

41. Abo-Haded HM, Elkablawy MA, Al-Johani Z, Al-Ahmadi O and El-Agamy DS. Hepatoprotective effect of sitagliptin against methotrexate induced liver toxicity. PLoS One 12: e0174295, 2017.

42. Peh HY, Tan WS, Liao W and Wong WS: Vitamin E therapy beyond cancer: Tocopherol versus tocotrienol. Pharmacol Ther 162: 152-169, 2016.

43. Yüncü M, Bükücü N, Bayat N, Sencar L and Tarakcioglu M: The effect of vitamin $\mathrm{E}$ and L-carnitine against methotrexate-induced injury in rat testis. Turk J Med Sci 45: 517-525, 2015.

44. Pyrhönen S, Kuitunen T, Nyandoto P and Kouri M: Randomised comparison of fluorouracil, epidoxorubicin and methotrexate (FEMTX) plus supportive care with supportive care alone in patients with non-resectable gastric cancer. Br J Cancer 71: 587-591, 1995.

45. Drago JR, Nesbitt JA, Badalament RA and Smith J: Chemotherapy and vitamin $\mathrm{E}$ in treatment of $\mathrm{Nb}$ rat prostate tumors. In Vivo 2: 399-401, 1988

46. Fu JY, Htar TT, De Silva L, Tan DM and Chuah LH: Chromatographic separation of vitamin E enantiomers. Molecules 22: pii: E233, 2017.

47. Dias MF, Sousa E, Cabrita S, Patricio J and Oliveira CF: Chemoprevention of DMBA-induced mammary tumors in rats by a combined regimen of alpha-tocopherol, selenium, and ascorbic acid. Breast J 6: 14-19, 2000.

48. Yiang GT, Chen JN, Lin PS, Liu HC, Chen SY and Wei CW Combined treatment with vitamin $\mathrm{E}$ and gefitinib has synergistic effects to inhibit TGF- $\beta 1$-induced renal fibroblast proliferation. Mol Med Rep 13: 5372-5378, 2016.

49. Uchihara Y, Ueda F, Tago K, Nakazawa Y, Ohe T, Mashino T, Yokota $S$, Kasahara T, Tamura $H$ and Funakoshi-Tago $M$. Alpha-tocopherol attenuates the anti-tumor activity of crizotinib against cells transformed by NPM-ALK. PLoS One 12: e0183003, 2017.

50. Peralta EA, Viegas ML, Louis S, Engle DL and Dunnington GL: Effect of vitamin $\mathrm{E}$ on tamoxifen-treated breast cancer cells Surgery 140: 607-615, 2006.

51. Chang H, Li C, Huo K, Wang Q, Lu L, Zhang Q, Wang Y and Wang W: Luteolin prevents $\mathrm{H} 2 \mathrm{O} 2$-induced apoptosis in $\mathrm{H} 9 \mathrm{C} 2$ cells through modulating Akt-P53/Mdm2 signaling pathway. Biomed Res Int 2016: 5125836, 2016.

52. Miyazato H, Taira J and Ueda K: Hydrogen peroxide derived from marine peroxy sesquiterpenoids induces apoptosis in HCT116 human colon cancer cells. Bioorg Med Chem Lett 26: 4641-4644, 2016

53. Wang C, Wang G, Liu H and Hou YL: Protective effect of bioactive compounds from Lonicera japonica Thunb. Against $\mathrm{H} 2 \mathrm{O} 2$-induced cytotoxicity using neonatal rat cardiomyocytes. Iran J Basic Med Sci 19: 97-105, 2016.

54. ElAttar TM and Virji AS: Inhibition of growth in oral squamous carcinoma cells by cyclopentenone prostaglandins: comparison with chemotherapeutic agents. Prostaglandins Leukot Essent Fatty Acids 56: 461-465, 1997.

55. Alleva R, Benassi MS, Pazzaglia L, Tomasetti M, Gellert N, Borghi B, Neuzil J and Picci P: Alpha-tocopheryl succinate alters cell cycle distribution sensitising human osteosarcoma cells to methotrexate-induced apoptosis. Cancer Lett 232: 226-235, 2006. 